\title{
顎口腔機能に関する我々の研究の流れ
}

Advances of our Researches on the Stomatognaghic Function

\author{
○丸山剛郎 \\ Takao Maruyama
}

大阪大学歯学部歯科補緅学第一講座

1st Department of Prosthetic Dentistry, 0saka University Faculty of Dentistry

顎口腔機能研究会が1982年に産声を上げてか ら今回で40回を迎えることになった。 その間における大阪大学歯学部歯科補緅学第一 講座が本研究会において発表を行なった内容に ついてその流れを述べることで小生の青を果た したい。

最初に本研究会において行なわれた我が教室 の研究発表を年代順に列挙する。

1983 年

1. 咀嚼筋の Silent Periodについて 中村公雄

2. Tapping 運動時における Silent period の変化について

中村公雄、赤西正光、高島史男、中村隆志、 丸山剛郎

1984 年

3. 咀嚼運動の恒常性と部位別咀嚼の特徵に関 する研究

瑞森崇弘、桑原俊也、中村康弘、桑原隆男、 西尾公一、宮内修平、丸山剛郎

4. Sirognathograph とパーソナルコンピュー タにより構成した下顎運動記録・解析シス テム

瑞森崇弘、桑原隆男、西尾公一、宮内修平、 丸山剛郎

1985 年

5. 咀㘄筋機能の分析に関する研究 一閉口筋 活動の同調性について一

石垣尚一、石井弘二、奥田眞夫、赤西正光、 丸山剛郎

6. 咀嚼運動に関する臨床的研究一各種食品
の影響についてー

桑原隆男、喜多村絵里、守屋啓吾、中村康 弘、瑞森崇弘、西尾公一、宮内修平、丸山 哃郎

1986 年

7. 身体の平衡が䂓口䭪機能に及ぼす影響につ いて（その1）

石井弘二、石垣尚一、奥田眞夫、赤西正光、 丸山剛郎

8. 咀嚼運動における䫈関節変化の及ぼす影響 に関する研究 一復位性関節円板前方転位 に関してー

桑原俊也、宮内修平、丸山剛郎

9. 咀罚運動に咬合因子が及ぼす影響に関する 臨床的研究

西尾公一、宮内修平、丸山剛郎

10.身体の平衡が顎口腔機能に及ぼす影響につ いて(その 2)

石井弘二、井上俊二、奥田眞夫、赤西正光、 丸山剛郎

11. 頭部側面 X線規格写真による顎顔面形恁と 咀嚼筋機能との関連性

奥田眞夫、石井弘二、石垣尚一、赤西正光、 丸山㴊郎

12. 咀罚運動と筋活動の関連性（その1） 東和生、高島史男、赤西正光、宮内修平、 丸山剛郎

13. 咀楒運動分析による鿓口腔機能診断 丸山剛郎、瑞森崇弘、宮内修平

1987 年

14. 臼歯部交叉咬合が頢口腔機能に及ぼす影響 
に関する研究

中南匡史、西尾公一、宮内修平、丸山剛郎

15. 阪大一補方式䫟口腔機能計測、記録、解析 システムについて

西塔治、大前泰三、井上俊二、石井弘二、

石垣尚一、奥田眞夫、中村隆志、赤西正光、 丸山剛郎

16. 周波数分析による等尺性負荷時䫈筋の疲労 に関する筋電学的評価

赤西正光、石垣尚一、丸山㴊郎

17. 咬合接触部位が咀毗筋活動に及ぼす影響に 関する研究

高島史男、東和生、相馬季世子、丸山剛郎

18. Sironathograph Analysing System II

（SGG/AS II) について

三間修司、東和生、瑞森崇弘、山田広司、 宮内修平、丸山剛郎

19. 咀楒運動に歯根膜内麻酔が及ぼす影響に関 する臨床的研究

中村康弘、三間修司、瑞森崇弘、丸山剛郎

1988 年

20.身体の平衡が顥口腔機能に及ぼす影響につ いて（その $3 ）$

石井弘二、大前泰三、奥田眞夫、瑞森崇弘 赤西正光、丸山剛郎

21. 頢口腔機能の臨床的評価 ータッピング運 動時での筋電図的評価 -

赤西正光、大前泰三、東和生、石垣尚一、

奥田眞夫、中村隆志、丸山剛郎

22. 咀罚運動の分析に現れる咬合の異常 第 2

報 咀䍛運動分析項目と咬合の異常との関 連

瑞森崇弘、居相暢之、吉田真理、小川弘枝、 奥田眞夫、宮内修平、丸山剛郎

23. 矯正治療症例の咀喂運動分析

日野絵里、吉田真理、西尾公一、黒田康子、 宮内修平、丸山剛郎

24. 筋電図診査の臨床応用に関する研究

第 1 報 筋活動の評価法法について

石垣尚一、吉川健司、仲谷江美子、大前泰 三、西塔治、井上悛二、石井弘二、奥田眞

夫、中村隆志、赤西正光、丸山剛郎

1989 年

25. 顎機能異常の検査、診断、治療法に関する アンケート調查
古屋良一、丸山剛郎、小林義典、森谷良彦

26. 咀喟運動の分析に現れる咬合の異常 第 3

報 被験食品の硬さの影響

吉岡慎郎、瑞森崇弘、東和生、桑原俊也、 柴田柾樹、宮内修平、丸山剛郎

27. 身体の平衡が頻口腔機能に及ぼす影響につ いて（その 4 )

石井弘二、赤西正光、丸山剛郎

1990 年

28. 全国ネット化による下頻運動機能の検査診 断データベース構築に関する研究

規格化検討グループ 一頻機能異常の検査 法に関するアンケート調査一

丸山剛郎、古屋良一、小林義典、森谷良彦

29. シロナソグラフ・アナライジング・システ ムによる咀緭運動のコンピュータ診断に関 する研究

瑞森崇弘、吉岡慎郎、中南匡史、宮内修平、 丸山剛郎

30．下䪽運動時の切歯点回転角度の関する臨床 的研究 第1 報 頢関節音との関連性 石垣尚一、間藤哲司、大前泰三、井上俊二、 赤西正光、丸山剛郎

31. 下頢咬合业曲と䫑口腔機能異常の関連性に 対する臨床的研究

伊藤博子、広島正樹、瑞森崇弘、宮内修平、 丸山㴊郎

32. 咀嚼機能の左右側差と頭位との関連性につ いて

奥田県夫、岩佐麻美、上田恭史、間藤哲司、 仲谷江美子、大前泰三、赤西正光、丸山剛 郎

1991 年

33. 咀喟運動におけるローテーションパターン に関する臨床的研究 第 1 報 トランスレ ーションパターンとの関連性

間藤哲司、石垣尚一、赤西正光、丸山剛郎

34. 発語における下頻運動に咬合異常が及ぼす 影響に関する研究

吉岡慎郎、小河弘枝、桑原俊也、丸山剛郎

これら 34 題の研究発表について、その順序 を研究分野に分類し、その要約を述べる。

A. 咀罚運動に関する研究

a.咀喟運動の生理学 
(1)咀嚼運動の恒常性と部位別咀嚼の特徵に関す る研究

咀嚼運動経路が臨床的に応用できるほどの恒 常性を備えているかを検討することを目的とし て、正常者 6 名を用いて日を異にして 3 回ガム 及びサラミンーセージ咀嚼を記録した。さらに 咀嚼部位を犬歯部、小臼歯部、大臼歯部それぞ れに限定した際の咀嚼運動経路の比較も行った。 その結果、咀嚼運動経路は被験者毎に特徵的で あったが、各個人内では高い恒常性が認められ た。また部位別咀嚼に関しては、大臼歯から小 臼歯、犬歯部に移行するにつれて左右的咀嚼幅 が減少する傾向が被験者に共通して認められた。

(2)咀嚼運動に関する臨床的研究

一各種食品の影響についてー

食品の性状の違いが咀嚼運動に与える影響を 知ることを目的として正常者 6 名を用いて、性 状の異なる食品（ガム、マシュマロ、チーズ、 レーズン、パン、生ニンジン、アーモンド、ス ルメ）の咀嚼運動を比較検討した。その結果、 食品の性状と咀嚼運動の分析結果との間に特徵 的な関連性が認められた。即ち、食品の性状の 変化により起こる咀嚼運動の変化を顎口腔系の 診査診断に応用できる可能性が示唆された。

(3)咀畄運動に歯根膜麻酔が及ぼす影響に関する 臨床的研究

咀嚼運動に歯根膜内麻酔が及ぼす影響を検討 するために、被験者 4 名に対して習慣性咀㘁側 下顎第一大鼠歯部之上䪽対合歯を含めた同第一 大臼歯に歯根膜内麻酔を行ない麻酔前の咀毞運 動をこれらの麻酔後の咀嚼運動を比較した。そ の結果、歯根膜麻酔により咀嚼運動のパラメタ 一の標準偏差が増加する傾向にあった。この変 化は食品の性状の違いに影響されていなかった。 また下鿓のみの麻酔と上下頢麻酔とを比較した ところ変化の傾向が反対である場合がみられた。

(4)咀嚼運動におけるローテーションパターンに

関する臨床的研究 第一報 トランスレーシ ョンパターンとの関連性

咀嚼運動中の下鿓切歯点のローテーションの 分析を、顎口腔機能診査の一助とすることを目 的として、正常者15名を用いて、咀罚運動中の
下顎切歯点のトランスレーションとローテーシ ョンの関連性を検討した。その結果、正常者に 特徵的なローテーションパターンの存在が明ら かになり、さらにローテーションパターンとト ランスレーションパターンの間には特徵的な対 态関係があることが明らかになった。

b.咬合と咀嚼運動の関わりに関するもの

(1)咀嚼運動に咬合因子が及ぼす影響に関する臨 床的研究

正常者に認められる典型的咀嚼パターンであ るCタイプとGタイプの機能的特徵を明らかに する目的で、正常者22名（Gタイプ 10名、C タイプ 12名）の咀嚼運動を検討した。その結 果、GタイプとCタイプとの間には咀嚼運動の パラメターに関して違いがあることが明らかに なった。またCタイプの者は、食品の正常にか かわらずCタイプの咀嚼パターンを示したが、 Gタイプの者の食品の性状に対する対応は様々 であった。すなわち、Cタイプと $G$ タイプの間 には機能的に差異があることが示唆された。

(2)臼歯部交叉咬合が顎口腔機能に及ぼす影響に 関する研究

臼歯部交叉咬合が顎口腔機能に及ぼす影響を 明らかにするために、正常者5名、臼歯部交叉 咬合を有する被験者22名の咀嚼運動を分析した。 その結果、臼歯部交叉咬合に特徽的に咀嚼パタ ーンが明らかになった。さらにこれらの特徵的 な咀嚼パターンは任意咀嚼よりも、臼歯部交叉 咬合の認められる部位での部位別咀嚼において さらに高頻度に認められた。

(3)咀嚼運動の分析に現れる咬合の異常 第 2 報 咀嚼運動分析項目と咬合の異常との関連 咀毗運動と咬合異常の関連性を知ることを目 的として、120名の被験者の咀罚運動を咀罚運 動分析ソフトウエアを用いて分析した。その結 果、各種咬合異常にそれぞれ特徵的なパラメタ 一が存在した。すわなち、咀嚼運動の分析䊅果 をみることにより咬合状態の診断ができる可能 性が示唆された。

(4)矯正治療症例の咀嚼運動分析

骨格性反対咬合の一症例についてその審美性 
を改善するために矯正治療を行い、併せて機能 性の改善についても咀嚼運動分析を用いて検討 した。その結果、術前に認められた異常咀嚼パ ターンは動的治療中には著しく乱れたが、矯正 治療終了時には各種異常咀嚼パターンは消失し た。即ち矯正治療により審美性の回復と同時に 機能の回復が図られたことが明らかになった。

(5)咀嚼運動の分析に現れる咬合の異常

第 3 報 被験食品の硬さの影響

被験食品の硬さの違いが各種咬合異常を有す る被験者の咀䁌運動にどの様に反映されるのか を知る目的で、120名の被験者のソフトガム勗 嚼及びハードガム咀罚を比較検討した。その結 果、被験食品の硬さの増加と各種咬合異常者の 咀嚼リズムの乱れや各相時間の変化との間には 特徵的な関連性があった。即ち被験食品の硬さ を変化させることにより、各種咬合異常をより 特徵的に診断できる可能性が示唆された。

c. 咀喂筋と咀絪運動の関わりに関するもの

(1)咀嚼運動と筋活動の関連性（その1)

咀囎運動における咀喟筋活動の様相の変化が 咀嚼パターンにどの様な関連性をもって現れて くるかを知る目的で、正常者 3 名を用いて、粘 度の異なる 2 種類のガム咀罚時の咀嚼運動及び 咀䁤筇活動を比較検討した。その結果、開口相 時間、最下方点の前後座標、最大開ロスピード と両側咬筋・側頭筋前腹の筋放電間隔・閉口相 時間の間に、また咀嚼周期と咀罚側咬筋 - 側頭 筋前腹の筋放電持続時間の間に関連性が示唆さ れた。すなわち、咀嚼パターンと咀嚼筋活動の 間には密接な関連性がある可能性が示唆された。

d. 䪽関節と咀嚼運動の関わりに関するもの

(1)咀嚼運動における颚関節変化の及ぼす影䪪に

関する研究

一復位性関節円板前方偏位に関して一

咀嚼運動分析を額関節異常の診断の一助とす ることを目的として、復位性関節円板前方偏位 患者11名、正常者10名の咀嚼パターンを比較検 討した。その結果、復位性関節円板前方偏位患 者では非咀嚼側に対して凹状の開口路が特徵的 に多く認められた。また復位性関節円板前方偏 位患者のうち、咀嚼中にクリックの認められる
患者では、開口路と閉口路の交叉するクロスオ ーバーパターンが特徵的に多く認められた。

(2)下顎運動時の切歯点回転角度に関する臨床的 研究 第一報 額関節音との関連性

下顎切歯点における運動解析により顎関節部 の運動状態を把握することを目的として、䫈関 節雑音を有する者 10 名、正常者 5 名の最大開閉 口運動中の下頻切歯点回転角度を検討した結果、 下頻切歯点の回転は、頻関節雑音発生時に大き く変化し、雑音発生前後の下顎頭の運動方向を 下鿓切歯点回転から推察することができた。

B. 筋電図に関する研究

a.サイレントピリオドに関するもの

(1)咀嚼筋のSilent periodについて

silent periodに関する過去の研究について、 総論的に解説を行った。

(2)Tapping 運動時における Silent periodの変 化について

正常者、TMJ患者の両側咬笳、側頭筋前腹 の Tapping 運動時における Silent period の分析を行った結果、 T M J 患者では Silent period の出現率、持続時間の推移、SD值に 特徵がみられた。

b.周波数分析に関するもの

(1)周波数分析による等尺性負荷時顎筋の疲労に 関する筋電学的評価

クレンチング時の頻筋表面筋電図を周波数分 析し、機能時䪽笳の正常範囲の判断基準值を設 定した。判断基準值を各被験者にあてはめたと ころクレンチおよびその持続において筋機能の 異常状態が頻繁に現れ、また、その付帯症状と して疲労、疼痛が認められた。このことより、 クレンチが蒷機能異常に結びつく可能性が十分 にあると考えられる。

c.咬合接触に関するもの

(1)咬合接触部位が咀嚼筋活動に及ぼす影響に関 する研究

後方歯群欠損に伴う咬合接触部位の減少が咀 礵筋活動に及ぼす影響を知る目的でシミュレー ション実験を行なった結果、欠損歯数の增加に 
より最大咬みしめ時の総筋活動量が減少する傾 向がみられた。両側欠損を想定した場合のほう が偏側欠損の場合より総筋活動量の減少は顕著 であった。また、偏側欠損の場合、欠損側のみ ならず非欠損側の筋活動量も減少した。

\section{d. 診査・分析・評価に関するもの}

(1)咀嚼筋機能の分析に関する研究

一閉口筋活動の同調性についてー

Tapping 運動時の開口路における側方への偏 位パターンと閉口筋の筋活動の開始点、終了点 との関連性を調べた結果、筋活動開始より歯牙 接触に至るまでの時間は偏位パターンにより異 なり、正常者と異常者で異なった結果を得た。

(2)顎口腔機能の臨床的評価

ータッピング運動時での筋電図的評価一

タッピング運動時の咀嚼筋筋電図について $M G$ Mフト開発を行ないメラーの方法に準じ た方法で分析を行なった。䪽機能の正常範囲の 基準設定について、左右差では各パラメターで その可能性があり、特にピーク位置の割合は正 常者の範囲が設定可能であると思われる。

\section{(3)筋電図診查の臨床応用に関する研究}

\section{第一報：筋活動の評価方法について}

筋電図診查を顎口腔機能診查の一手段として 臨床的に応用する際の有用性を高めることを目 的として、一連の詮査項目を組合わせ、各人の 筋の機能状態をより総括的に、簡便に把握する ことができる診查方法を考案した。本診査によ り得られた結果は各被験者ごとの特徵的な筋活 動パターンの存在をうかがわせるものであり、 本診查が各人の咀礵筋状態を把握する機能診査 として臨床的に応用し得ることが示唆された。

C. 顔面・䪽形態、頭位と咀嚼機能に関する研 究

(1)頭部側面X線規格写真による顎顔面形態と咀 楒筋機能の関連性

個性正常咬合者63名(男性53名、女性10名)に おける顎顔面形態を特に咬合平面を中心に分析 したところ、咬合平面は下額下縁平面および咬 筋前縁線との間に有意な相関性を示した。咬合 平面傾斜角が顎口腔機能とどの様な関連性を有
しているかを知る目的でタッピング運動時の下 顎運動経路および咬筋筋電図の記録を行ったと ころ、下䫈運動経路は咬合平面傾斜角が異なる にも関わらず頭蓋に対してほぼ同一傾斜を示し、 咬合接触前の咬筋活動持続時間が咬合平面倾斜 角の大きな被験者において短い傾向が示された。

(2)下顎咬合祡曲と顎口腔機能異常の関連性に対 する臨床的研究

顎口腔機能異常患者をClosed 1ock患者群、 Reciprocal c1ick患者群、M.P.D.Synd rome患者 群の3 群に分類し、各群間および個性正常咬合 者群との間で、下影咬合彗曲度を比較検討した。 その結果、Closed 1ock 患者群、Reciprocal c1 ick 患者群で下頂臼歯の舌側傾斜が強く、

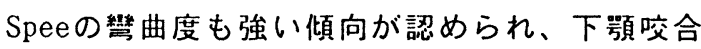
彗曲が顎口腔機能異常と関連していなった。

(3)咀罚機能の左右側差と頭位との関連性につい

\section{$\tau$}

頻口腔機能に自覚的他覚的に異常を認めない 健常成人を対象に、主咀嚼側、頭位の側屈側、 頭位と主咀嚼側との一致性と咀嚼リズムおよび 咀嚼筋活動の左右側差との関係について検討し た結果、以下の結論を得た。

1. 任意咀嚼における咀嚼側をもとにした客観 的主咀嚼側、被験者が自覚している主観的主咀 嚼側ともに右側の者が多く、その一致率は右側 で $91.7 \%$ 、左側で $71.4 \%$ であった。

2. 頭位の側屈側は右側の者の方が多かったが、 主咀嚼側との間には明らかな関連性が認められ なかった。

3. 頭位の側屈側と客観的主咀㗍側の一致性と 咀楒リズムとの間には明らかな関連性が認めら れなかった。咀嚼筋活動については、一致群で 側頭筋の咀嚼側筋活動比率が主咀罚側咀嚼にお いて大きい傾向が示された。

D. 身体の平衡と䪽口腔機能の関する研究

(1)身体の平衡が頢口腔機能に及ぼす影響につい $\tau$

頢口腔機能の左右不均衡と、頢顔面形態の左 右非対称および身体の重心との関連について分 析したところ以下の結論を得た。

1. 最大かみしめ時の筋活動量あるいは咀嚼運 
動の分析項目に左右不均衡が認められない者で は、咀嚼運動のリズムの変異係数および最下方 点の標準偏差が小さく咀噮運動が安定していた。 2. 習慣性咀䇿側を自賞する者では、習慣性咀 嚼側の側頭筋前部の最大かみしめ時の筋活動量 が大きい傾向が認められ、習慣性咀嚼側を自覚 しない者では、自覚する者と比較して咀嚼リズ ムが速い傾向が認められた。従って、習慣性咀 嚼側が頻口腔機能の左右不均衡を反映している ことが示された。

3. 䫟顔面形態の左右非対称については、幅径 の大きい側で最大かみしめ時の咬筋筋活動量が 大きく、下鿓の偏位側の咬筋、側頭筋後部およ び頡二腹筋前腹の筋活動量が大きい傾向が認め られ、顎口腔機能との関連性が示された。

4. 重心は最大かみしめにより安定し、重心変 位側において咀噮周期が短く、咬筋、側頭筋前 部および後部の最大かみしめ時の筋活動量が大 きい傾向が認められた。重心変位側と頢顔面形 態の側方成分の大きい側とは一致する傾向が認 められた。従って、重心は顎口腔機能および顎 顔面形態と関連していることが示された。

E. 発語における下碩運動に関する研究

(1)発語における下䪽運動が咬合異常が及ぼす影 響に関する研究

発語における下類運動に咬合異常が及ぼす影 響を知るために、まず各種不正咬合者 60 名の発 語時下㯋運動域境界を正常咬合者10名の運動域 境界と比較した。その結果、発語時下䪽運動域 境界は切端咬合では上方に、過蓋咬合では下方 に、開咬では前方に、前歯部反対咬合では後下 方に、臼歯部異常群では正常侧に、各々特徵的 に偏位したが、運動域の幅径には差が認められ なかった。さらに咬合異常の一つとして、実験 的に急傾斜な矢状切歯路角を個性正常咬合者 11 名に付与し発語時下鿓運動域境界の変化を検討 した。その結果、発語時下額運動域境界は後下 方に変化したが運動域の幅径は変化しなかった。

\section{F . 下頻運動記録解析システムーシロナソグラ フ・アナライジング・システムに関する研} 究

(1) Sirognathograph とパーソナルコンピュータ により構成した下䫟運動記録・解析システム
顎機能への干渉が少なくしかも臨床応用が簡 便に行える下頻運動測定装置 Sirognathograph (Siemens, Germany)とパーソナル・コンピュー 夕PC-9800(NEC)を組合わせて下頻運動記録・解 析システムを構築した。これは研究室だけでな く一般的な歯科臨床にも応用できるものである。

\section{(2) Sironathoguraph Analysing System II}

咀翾運動時の下頡運動の状態をさらに詳しく 分析するため、シロナソグラフ・アナライジン グ・システムのハードウェア・ソフトゥェアを 変更しシロナソグラフ・アナライジング・シス テム川の開発を行なった。

\section{G. 顎口腔機能診查・診断システム}

(1)咀嚼運動分析における䪽口腔機能診断

150名の被験者について 咀還運動と顎口腔系 の各要素の関連を検討した結果各々の要素の異 常に特徵的な咀嚼運動の分析結果が現れたため に、逆に咀嚼運動の分析から顎口腔系の各要素 の異常の有無を診断できる可能性が示唆された。

(2)阪大一補方式顎口腔機能計測、記録、解析シ ステムについて

筋電図、下顎運動、咬合音、頻関節音、重心 位置等を棇合的に知り得かつ膨大量のデータを 迅速に処理する顎口腔機能計測、記録、解析シ

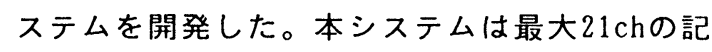
録および16chについての同時解析が可能である。

(3)シロナソグラフ・アナライジング・システム による咀嚼運動のコンピュータ診断に関する 研究

鿓口腔機能異常患者の機能診査としてシロナ ソグラフ・アナライジング・システムによる咀 嚼運動の診査を行い、臨床生理咬合の観点から 各種咬合異常や咀嚼筋異常、頻関節異常を診断 した。この診断の際の知識を一般開業医でも利 用可能なエキスパート・システム化を試みた。

\section{H. その他}

(1)頻機能異常の検査、診断、治療法に関するア ンヶート調查

(2)全国ネット化による下頻運動機能の検査診断 データベース構築に関する研究 